\title{
The influence of nickel on the adhesion ability of Desulfovibrio desulfuricans
}

\author{
F.A. Lopes ${ }^{a}, *$, P. Morin ${ }^{a}$, R. Oliveira ${ }^{a}$, L.F. Melo ${ }^{b}$ \\ ${ }^{a}$ Departamento de Engenharia Biológica, Universidade do Minho, 4710-057 Braga, Portugal \\ ${ }^{\mathrm{b}}$ Faculdade de Engenharia do Porto, Departamento de Engenharia Química, Universidade do Porto, Porto, Portugal
}

Received 27 January 2005; received in revised form 11 May 2005; accepted 5 July 2005

\begin{abstract}
The build-up of biofilms on metals surfaces may lead to severe corrosion, especially in the presence of sulphate-reducing bacteria (SRB). To prevent the deterioration of material caused by biofilms it is necessary to understand the processes governing biofilm development including mechanisms of cell adhesion. Additionally, corrosion of metallic surfaces due to bacteria may lead to the dissolution of metallic elements that may further affect adhesion and biofilm development. A study was carried out to evaluate how the presence of nickel in the substrata affects the adhesion ability of Desulfovibrio desulfuricans. The substrata tested were stainless steel 304 (SS), metallic nickel (Ni) and polymethylmetacrylate (PMMA), a non-metallic material used as control. The influence of nickel on SRB growth and its relation to adhesion was also checked. A statistically significant difference in the number of adhered cells to the materials tested was detected, with higher bacterial number on nickel, followed by SS and finally by PMMA. The higher number of SRB adhered to steel compared with PMMA may be explained by differences in hydrophobicity, in roughness and in the electron-acceptor character of the substrata. Additionally, bacterial growth was found to be positively affected by the presence of nickel as revealed by a significant increase in the specific growth rate of SRB in the presence of increased nickel concentrations.
\end{abstract}

(C) 2005 Elsevier B.V. All rights reserved.

Keywords: SRB; Bacterial adhesion; Stainless steel; Nickel

\section{Introduction}

The presence of micro-organisms on metal surfaces and their ability to carry out specific biochemical reactions can alter the physical/chemical conditions at the metal surface and lead to microbiologically influenced corrosion (MIC). Microbes in a biofilm may provoke or accelerate corrosion in several ways, e.g., by creating concentration and differential aeration cells, directly oxidising/reducing metallic atoms/ions and producing corrosive metabolic by-products that destroy the passivating films [1].

An important type of micro-organisms associated with corrosion failures of engineering structures made of cast iron, mild steel and stainless steel, aluminium, copper and their alloys in both aquatic and terrestrial environments, under anoxic and oxy-

\footnotetext{
* Corresponding author. Present address: Service de la corrosion et du comportement des matériaux dans leur environnement, Commissariat à l'Energie Atomique, CEA/Saclay, bâtiment 458, 91191 Gif-sur-Yvette Cedex, France. Tel.: +33169081620; fax: +33169081586 .

E-mail addresses: fil.lopes@ free.fr, falopes@ deb.uminho.pt (F.A. Lopes).
}

genated conditions, are the sulphate-reducing bacteria (SRB) [2-5]. SRB belong to a group of morphologically and nutritionally diverse anaerobic bacteria, which utilise sulphate (or other oxidized sulphur compounds) as an electron-acceptor for the dissimilation of organic compounds and produce sulphide [6]. The activities of SRB in natural and man-made systems are of great concern to many different industrial operations. In particular, nuclear power plants, service water systems, oil, gas and shipping industries are seriously affected by these bacteria [2,7].

Bacterial adhesion is considered the first stage in the formation of a biofilm. Substratum hydrophobicity has been considered one of the most important physico-chemical parameters involved in bacterial adhesion. An increase in hydrophobicity is frequently associated to an increase in the number of adhered cells to a substratum [8]. However, some studies reported a decrease in bacterial adhesion to metallic surfaces with the increase of hydrophobicity [9].

Also it appears that the ions released from the steel surface have a direct effect on the microbial growth and metabolism that influence bacteria-metal interaction and bacterial adhesion. 
For instance, sensitised stainless steel 304 surfaces presented a higher number of adhered cells compared to solution-annealed or oxidized surfaces. This was attributed to the increased release of iron from those surfaces that are susceptible to intergranular corrosion and to the fundamental role of this metal in microbial growth and metabolism [10].

Additionally, as emphasized by Feron [11], the alloying elements (chromium, nickel, molybdenum, vanadium, etc.) added to steels in order to improve their corrosion resistance might markedly affect bacterial growth, the attachment of bacterial cells to steel surfaces and the biofilm development.

The present work was undertaken to investigate the influence of nickel as part of the substratum composition on the adhesion ability of Desulfovibrio desulfuricans by studying the attachment of the bacteria to stainless steel 304 (SS), metallic nickel (Ni) and polymethylmetacrylate (PMMA), which is a non-metallic material and was used as control. Briefly, stainless steel is essentially a low carbon steel, containing chromium at $12 \%$ or more by weight. The corrosion resistance of stainless steel is due to the formation of a thin passive film [12]. This passive film is an amorphous structure of chemisorbed oxygen bonding to the surface with an electrostatic bonding between oxygen anions and metal cations [13]. This passive layer provides corrosion resistance in a wide variety of environments although it can break down under a number of environments including the presence of chloride, some organic acids and halides [13]. Nickel is an element included in many alloys, such as stainless steel, to increase their corrosion resistance. Nickel is also the base metal in a group of highly specialised alloys used in high temperature waters, such as in nuclear power reactors. The resistance to corrosion in different environments is closely related to its passive behaviour. The chemical composition of the passive film is still under debate; this layer consists either of oxide or of hydroxide [14,15].

\section{Materials and methods}

\subsection{Bacterial strain and growth conditions}

The sulphate-reducing bacterium used in this study was the strain $D$. desulfuricans DSM 642. The strain was stored at $4{ }^{\circ} \mathrm{C}$ in the culture medium and transferred monthly to maintain viability. This kind of bacteria has been frequently reported to be involved in microbiologically influenced corrosion [2,3].

Pure cultures of $D$. desulfuricans were grown in $50 \mathrm{~mL}$ culture medium in $100 \mathrm{~mL}$ serum-bottles, with continuous shaking at $26{ }^{\circ} \mathrm{C}$. The culture growth medium used was a modified Postgate medium $\mathrm{C}$ with the following composition $\left(\mathrm{g} \mathrm{L}^{-1}\right)$ : $\mathrm{NH}_{4} \mathrm{Cl}$, 1.1; $\mathrm{CaCl}_{2} \cdot 2 \mathrm{H}_{2} \mathrm{O}, 0.008 ; \mathrm{MgSO}_{4} \cdot 7 \mathrm{H}_{2} \mathrm{O}, 0.06 ; \mathrm{FeSO}_{4} \cdot 7 \mathrm{H}_{2} \mathrm{O}$, 0.007 ; yeast extract, 0.25 ; trace elements $(\mathrm{B}, \mathrm{Co}, \mathrm{Cu}, \mathrm{Mn}$, $\mathrm{Zn}$ ), $0.05 \mathrm{mg} \mathrm{L}^{-1}$ (each); $\mathrm{Na}_{2}$ EDTA.2 $\mathrm{H}_{2} \mathrm{O}, 0.02 ; \mathrm{KH}_{2} \mathrm{PO}_{4}$, $0.1 ; \mathrm{Na}_{2} \mathrm{HPO}_{4} \cdot 12 \mathrm{H}_{2} \mathrm{O}, 0.22$. Sodium lactate $(50 \%)$ was used as organic substrate with a concentration of approximately $13 \mathrm{~g} \mathrm{~L}^{-1}$ and $\mathrm{K}_{2} \mathrm{SO}_{4} 7.8 \mathrm{~g} \mathrm{~L}^{-1}$ as sulphate source. As a medium reductant, $430 \mathrm{mg} \mathrm{L}^{-1}$ of $\mathrm{Na}_{2} \mathrm{~S} \cdot 9 \mathrm{H}_{2} \mathrm{O}$ was used and $1 \mathrm{mLL}^{-1}$ of $1 \mathrm{~g} \mathrm{~L}^{-1}$ of resazurin was added as a redox indicator. After adjusting the $\mathrm{pH}$ at 7 , the medium was purged approximately
$15 \mathrm{~min}$ with high-purity nitrogen and then autoclaved at $120^{\circ} \mathrm{C}$ for $20 \mathrm{~min}$.

\subsection{Materials}

The substrata used in the adhesion experiments were small squared surfaces $(1 \mathrm{~cm} \times 1 \mathrm{~cm} \times 0.2 \mathrm{~cm}$ thickness $)$ of stainless steel 304 (UNS S 30400), nickel and polymethylmetacrylate.

The stainless steel (cold-rolled surface with a pickling finish) used had the following composition: $\mathrm{C}, 0.05 \%$; $\mathrm{Cr}, 17 \%$; Ni, 8.1\%; Mn, 1.34\%; Si, 0.36\%; Cu, 0.19\%; Mo, 0.18\%; Co, $0.13 \% ; \mathrm{V}, 0.09 \%$, the remaining mass consisting of Fe. The coupons of nickel (rolled-surface) presented a high purity (more than $99 \%$ Ni). Surface roughness was measured using a Surftest SV-502. All the specimens were analysed randomly three times for several parameters such as the mean surface roughness $\left(R_{\mathrm{a}}\right)$, the more universally recognised parameter of roughness, which is the arithmetic mean of the absolute departures of the roughness profile from the mean line, $R_{\mathrm{Z}}$ is the height of 10 irregular peaks in the profile, $R_{\mathrm{q}}$ is the average value of the square rate of the peak height and $R_{\max }$ corresponds to the maximum peak detected on the profile.

The coupons were cleaned with a commercial detergent, rinsed in tap water, rinsed in ethanol $96 \%$ and finally rinsed with filtered-sterilised distilled water. Following this procedure, they were stored in a dessiccator until use for the contact angle measurements and adhesion assays.

\subsection{Adhesion assays}

After approximately 40-46 h, corresponding to the exponential growth phase, the bacterial cells were harvested by centrifugation $(10 \mathrm{~min}, 5000 \mathrm{rpm})$, washed with the culture medium without lactate or yeast extract (ionic strength of the medium $=0.164 \mathrm{~mol} \mathrm{~L}^{-1}$ ) and resuspended in this solution to a concentration of approximately $4.3 \times 10^{7} \pm$ $2.3 \times 10^{6}$ cells mL ${ }^{-1}$ (assay 1 ) and $7.0 \times 10^{6} \pm 5.5 \times 10^{5}$ cells $\mathrm{mL}^{-1}$ (assay 2). These bacterial concentrations were determined by 4,6 diamidino-2-phenylindole (DAPI, Sigma-Aldrich) staining using conventional epifluorescence microscopy.

To maintain the anoxic conditions, the autoclaved centrifuge tubes were previously purged with nitrogen and the washing procedure of the cells was performed under nitrogen atmosphere.

Three coupons of each of the materials tested (SS, Ni and PMMA) were used in the adhesion assays. The coupons were inserted into a 24 well plate and $1.5 \mathrm{~mL}$ of the cellular suspension was added to each well. In order to avoid oxygen diffusion into the suspension, a paraffin layer was laid over each well. The plate was then kept in an orbital shaker at $26^{\circ} \mathrm{C}$ and $100 \mathrm{rpm}$ for $1 \mathrm{~h}$. The incubation time was optimised to allow a maximum of initially adhered cells per unit of coupon surface (data not shown). After incubation, coupons were gently rinsed with filtered-sterilised distilled water in order to remove poorly adhered bacteria. Each coupon was then immersed in formaldehyde $37 \%$ for at least $5 \mathrm{~min}$ to fix the cells, rinsed with filteredsterilised water, stained with a $0.1 \mathrm{mg} \mathrm{L}^{-1}$ DAPI solution for $5 \mathrm{~min}$ and finally rinsed with filtered-sterilised water before 
microscopic observation. Attached cells were enumerated by epifluorescence microscopy (Axioskop Zeiss, Germany) under oil immersion. Cells were enumerated at $1000 \times$ magnification and 20-30 different fields were randomly selected and counted for each surface. The adhesion assays were repeated twice.

\subsection{Contact angles}

The contact angles were measured automatically with the aid of an image analysis system (Kruss-GmbH, Hamburg, Germany). The images were recorded by a video camera connected to a PC, with an automatic measuring system (G2/G40). The contact angles were determined according to the sessile drop technique. The measurements were carried out at room temperature using high-purity water, diiodomethane and formamide as reference liquids. The data of surface tension components of the test liquids are given in Table 1. For each type of material, three replicates of at least 20 contact angle measurements were performed.

In order to obtain bacterial lawns for contact angle measurements, bacteria were grown as previously described and washed with a phosphate buffer $\left(\mathrm{NaCl}, 8.5 \mathrm{~g} \mathrm{~L}^{-1} ; \mathrm{KH}_{2} \mathrm{PO}_{4}, 0.27 \mathrm{~g} \mathrm{~L}^{-1}\right.$; $\mathrm{Na}_{2} \mathrm{HPO}_{4}, 1.42 \mathrm{~g} \mathrm{~L}^{-1}$ ). A $5.1 \times 10^{8}$ cells $\mathrm{mL}^{-1}$ suspension was then collected on $0.45 \mu \mathrm{m}$ pore diameter filters. Filters were maintained for $30 \mathrm{~min}$ in Petri dishes containing $1 \%(\mathrm{w} / \mathrm{v})$ agar with $10 \%(\mathrm{v} / \mathrm{v})$ glycerol to establish constant moisture content [16], The filters were then fixed onto microscope glass slides.

\subsection{Surface tension}

The surface tensions of each material and bacterial cells were calculated according to the approach of Van Oss et al. [17], using the values of the contact angles formed by water, formamide and diiodomethane on each material surface and on the bacterial lawns.

The surface tension and its related parameters were estimated by applying the following equation:

$(1+\cos \theta) \gamma_{1}=2\left[\sqrt{\gamma_{\mathrm{s}}^{\mathrm{LW}} \gamma_{1}^{\mathrm{LW}}}+\sqrt{\gamma_{\mathrm{s}}^{+} \gamma_{1}^{-}}+\sqrt{\gamma_{\mathrm{s}}^{-} \gamma_{1}^{+}}\right]$

where $\theta$ is the contact angle, $\gamma_{1}$ the total surface tension, $\gamma^{\mathrm{LW}}, \gamma^{+}$ and $\gamma^{-}$are the van der Waals, electron-acceptor and electrondonor parameters of the polar component $\left(\gamma^{\mathrm{AB}}\right)$ of the surface

Table 1

Surface tension components of water, diiodomethane et formamide (values in $\mathrm{mJ} \mathrm{m}^{-2}$ at $20^{\circ} \mathrm{C}$ )

\begin{tabular}{lllll}
\hline Surface tension $\left(\mathrm{mJ} \mathrm{m}^{-2}\right)$ & & & \\
\hline Liquid & $\gamma^{\text {Tot }}$ & $\gamma^{\mathrm{LW}}$ & $\gamma^{+}$ & $\gamma^{-}$ \\
\hline Water & 72.80 & 21.80 & 25.50 & 25.50 \\
Formamide & 58.00 & 39.00 & 2.28 & 39.60 \\
Diiodomethane & 50.80 & 50.80 & 0.0 & 0.0 \\
\hline
\end{tabular}

$\gamma^{\mathrm{LW}}$, apolar component of surface tension; $\gamma^{\mathrm{AB}}$, polar component of surface tension; $\gamma^{+}$, electron-acceptor parameter of the polar component of surface tension; $\gamma^{-}$, electron-donor parameter of the polar component of surface tension; $\gamma^{\text {Tot }}$, total surface tension. tension, respectively. The subscript (s) denotes the solid surface (material or cells) and (1) refers to the liquid used in each measurement.

\subsection{Hydrophobicity}

The degree of hydrophobicity of each material including bacterial cells was calculated according to the approach of Van Oss et al. [17].

$\Delta G_{\mathrm{SWS}}^{\mathrm{Tot}}=\Delta G_{\mathrm{SWS}}^{\mathrm{LW}}+\Delta G_{\mathrm{SWS}}^{\mathrm{AB}}$

$\Delta G_{\mathrm{SWS}}^{\mathrm{LW}}=-2\left(\sqrt{\gamma_{\mathrm{s}}^{\mathrm{LW}}}-\sqrt{\gamma_{\mathrm{w}}^{\mathrm{LW}}}\right)^{2}$

$\Delta G_{\mathrm{SWS}}^{\mathrm{AB}}=4\left(\sqrt{\gamma_{\mathrm{s}}^{+} \gamma_{\mathrm{w}}^{-}}+\sqrt{\gamma_{\mathrm{s}}^{-} \gamma_{\mathrm{w}}^{+}}-\sqrt{\gamma_{\mathrm{s}}^{+} \gamma_{\mathrm{s}}^{-}}-\sqrt{\gamma_{\mathrm{w}}^{+} \gamma_{\mathrm{w}}^{-}}\right)$

where $\Delta G_{\mathrm{SWS}}^{\mathrm{Tot}}$ is the total surface free energy of interaction between two surfaces of a solid material (s) immersed in water (w), $\Delta G_{\mathrm{SWS}}^{\mathrm{AB}}$ and $\Delta G_{\mathrm{SWS}}^{\mathrm{LW}}$ are the corresponding polar and apolar components, respectively.

According to the definition of hydrophobicity proposed by Van Oss and Giese [18], a surface is considered hydrophobic when the free surface energy of interaction between its molecules in the presence of water $\left(\Delta G_{\mathrm{SWS}}\right)$ is negative. Otherwise it is considered hydrophilic.

\subsection{Effect of nickel on bacterial growth}

In order to evaluate the influence of nickel on $D$. desulfuricans growth, nickel was added to the standard culture medium as $\mathrm{NiCl}_{2} \cdot 6 \mathrm{H}_{2} \mathrm{O}$. Nickel $\left(\mathrm{Ni}^{2+}\right)$ was tested at the following concentrations: $0.10 ; 0.85 ; 8.52$ and $85.2 \mu \mathrm{M}$. The control contained no nickel. All tested concentrations were assayed at least in triplicate.

The culture medium was prepared as described above. Three to four days old cultures were used as sources of bacterial inocula. After inoculation, the cultures were incubated with continuous stirring $(150 \mathrm{rpm})$ at $26^{\circ} \mathrm{C}$ and growth was followed by optical density at $620 \mathrm{~nm}$. Average specific growth rates were then determined for bacterial suspensions developed with the different nickel concentrations.

\subsection{Statistical analysis}

Adhesion experiments were performed in duplicate, each one using three coupons of stainless steel, nickel and polymethylmetacrylate. The results were expressed as mean \pm standard deviation (S.D.). To evaluate differences between means with a confidence level of $95 \%$, one-way analysis of variance (ANOVA) and a non-parametric Kruskall-Wallis tests were carried out using the SPSS software (version 11). It should be pointed out that the ANOVA test only allows knowing if the compared groups differ, but it does not specify where the significant difference is located. In order to find out which groups were significantly different to one another, post-hoc comparison (Bonferroni test) was applied. 


\section{Results}

\subsection{Adhesion assays}

Fig. 1 presents the results of the adhesion assays, showing that the three materials exhibited different susceptibilities to bacterial colonization. A statistically significant difference across the colonization of the three substrates was detected (KruskallWallis test first and second adhesion assays, $p=0.0<0.05$ ). A maximum of adhered cells was observed on nickel, followed by stainless steel 304 and polymethylmetacrylate. The same pattern was found independently of the initial bacterial concentration.

\subsection{Surface roughness}

Table 2 presents the surface roughness parameters determined for PMMA, SS and Ni substrata.

The results suggest that stainless steel was the rougher surface. However, the roughness parameters determined for stainless steel and nickel surfaces were similar.

\subsection{Contact angles and surface tension}

After determining the contact angle of water, formamide and diiodomethane on stainless steel 304, nickel and polymethylmetacrylate and on the bacterial lawns (Table 3), surface tensions were calculated following the Van Oss approach [17] (Table 3). This approach considers that the surface tension of a given substance comprises two components, one related to Lifshitz-van der Waals interactions $\left(\gamma^{\mathrm{LW}}\right)$ and another associated to polar interactions $\left(\gamma^{\mathrm{AB}}\right)$ of electron-acceptor electron-donor type, $\gamma^{+}$ and $\gamma^{-}$, respectively [19].

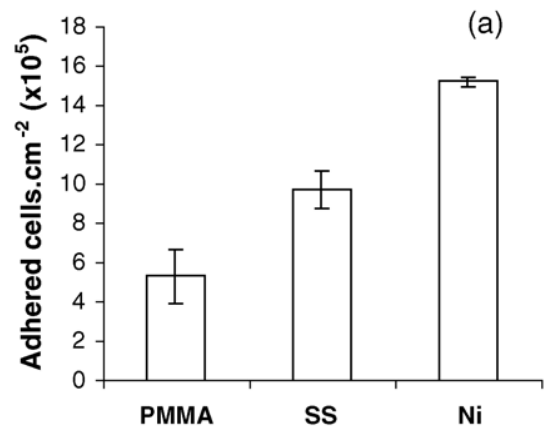

Table 3

Surface tension and surface tension components of the substrata and bacterial cells (values in $\mathrm{mJ} \mathrm{m}^{-2}$ at $20^{\circ} \mathrm{C}$ ) and contact angles (values in ${ }^{\circ}$ ) of stainless steel (SS), polymethylmetacrylate (PMMA), nickel (Ni) and the bacterial lawn with water $\left(\theta_{\mathrm{W}}\right)$, diiodomethane $\left(\theta_{\mathrm{D}}\right)$ and formamide $\left(\theta_{\mathrm{F}}\right)$

\begin{tabular}{lllll}
\hline & PMMA & SS & Ni & D. desulfuricans \\
\hline$\theta_{\mathrm{W}}$ & $70.18 \pm 3.13$ & $74.93 \pm 5.01$ & $59.10 \pm 2.38$ & $43.07 \pm 2.05$ \\
$\theta_{\mathrm{F}}$ & $47.94 \pm 3.39$ & $42.73 \pm 2.85$ & $58.87 \pm 3.91$ & $59.75 \pm 4.48$ \\
$\theta_{\mathrm{D}}$ & $44.40 \pm 2.24$ & $45.58 \pm 2.50$ & $30.14 \pm 1.04$ & $68.66 \pm 3.80$ \\
$\gamma^{\mathrm{LW}}$ & 37.33 & 36.70 & 44.16 & 23.62 \\
$\gamma^{+}$ & 0.78 & 2.28 & 0.0 & 0.06 \\
$\gamma^{-}$ & 9.74 & 3.89 & 33.06 & 59.75 \\
$\gamma^{\mathrm{AB}}$ & 5.51 & 5.95 & 0.0 & 3.90 \\
$\gamma^{\mathrm{Tot}}$ & 42.84 & 42.65 & 44.16 & 27.52 \\
\hline
\end{tabular}

Contact angle results are indicated as average value \pm standard deviation. $\theta_{\mathrm{W}}$, water contact angle; $\theta_{\mathrm{F}}$, formamide contact angle; $\theta_{\mathrm{D}}$, diiodomethane contact angle; $\gamma^{\mathrm{LW}}$, apolar component of surface tension; $\gamma^{\mathrm{AB}}$, polar component of surface tension; $\gamma^{+}$, electron-acceptor parameter of the polar component of surface tension; $\gamma^{-}$, electron-donor parameter of the polar component of surface tension; $\gamma^{\text {Tot }}$, total surface tension.

According to the results presented in Table 3, all tested materials had similar total surface tension values and were predominantly electron donors $\left(\gamma^{-} \gg \gamma^{+}\right)$with a very small electron-acceptor parameter $\left(\gamma^{+}\right)$, especially PMMA and bacterial cells. Therefore, the $\gamma^{\mathrm{AB}}\left(\gamma^{\mathrm{AB}}=2\left[\gamma^{+} \gamma^{-}\right]^{1 / 2}\right)$ parameter presented very low values for these two surfaces. While nickel presented no electron-acceptor ability at all, stainless steel was characterised by the highest value of $\gamma^{+}$.

In all cases, the apolar component $\left(\gamma^{\mathrm{LW}}\right)$ had a much greater contribution for the overall value of surface tension than the polar component $\left(\gamma^{\mathrm{AB}}\right)$. Results also showed that nickel is characterised by the highest value of $\gamma^{-}$(electron-donor parameter of the polar component of the surface tension).

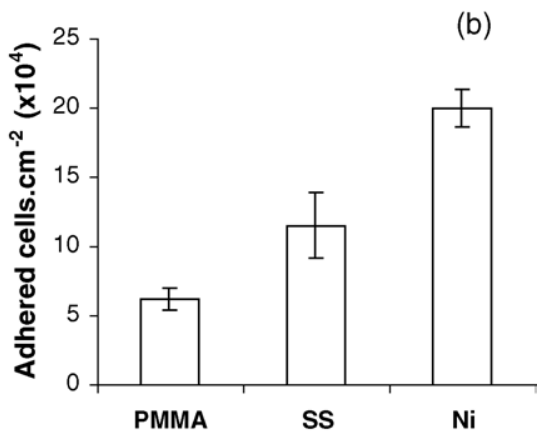

Fig. 1. Adhesion of Desulfovibrio desulfuricans to PMMA, SS and Ni. (a) First assay, $4.32 \times 10^{7} \pm 2.34 \times 10^{6}$ suspended cells $\mathrm{mL}^{-1}$; (b) second assay, $7.03 \times 10^{6} \pm 5.48 \times 10^{5}$ suspended cells $\mathrm{mL}^{-1}$.

Table 2

Roughness parameters of polymethylmetacrylate (PMMA), stainless steel 304 (SS) and nickel (Ni) surfaces

\begin{tabular}{|c|c|c|c|c|}
\hline Material & $R_{\mathrm{a}}(\mu \mathrm{m})$ & $R_{\mathrm{Z}}(\mu \mathrm{m})$ & $R_{\mathrm{q}}(\mu \mathrm{m})$ & $R_{\max }(\mu \mathrm{m})$ \\
\hline PMMA & $0.047 \pm 0.008$ & $0.553 \pm 0.128$ & $0.068 \pm 0.013$ & $0.967 \pm 0.305$ \\
\hline SS & $1.177 \pm 0.081$ & $11.257 \pm 1.984$ & $1.580 \pm 0.173$ & $14.053 \pm 3.130$ \\
\hline $\mathrm{Ni}$ & $1.000 \pm 0.214$ & $8.687 \pm 1.157$ & $1.345 \pm 0.280$ & $10.963 \pm 1.282$ \\
\hline
\end{tabular}

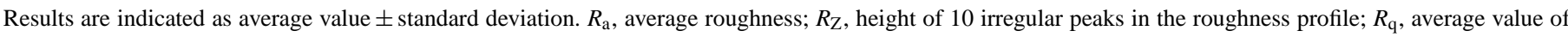
the square rate of the heights, $R_{\max }$, maximum peak detected on the profile. 
Table 4

Surface free energy of interaction between two surfaces of material (s) immersed in water $\left(\Delta G_{\text {SWS }}\right)$ and its apolar and polar components for the different materials and for the bacterial cells (values in $\mathrm{mJ} \mathrm{m}^{-2}$ at $20^{\circ} \mathrm{C}$ )

\begin{tabular}{lccr}
\hline Material/cells & $\Delta G_{\mathrm{SWS}}^{\mathrm{LW}}$ & $\Delta G_{\mathrm{SWS}}^{\mathrm{AB}}$ & $\Delta G_{\text {SWS }}^{\mathrm{Tot}}$ \\
\hline PMMA & -4.15 & -32.14 & -36.29 \\
$\mathrm{SS}$ & -3.86 & -43.58 & -47.45 \\
$\mathrm{Ni}$ & -7.81 & 14.14 & 6.33 \\
D. desulfuricans & -0.07 & 51.42 & 51.35 \\
\hline
\end{tabular}

$\Delta G_{\text {SWS }}^{\mathrm{LW}}$, apolar component of the surface free energy of interaction between two surfaces of material (s) immersed in water; $\Delta G_{\mathrm{SWS}}^{\mathrm{AB}}$, polar component of the surface free energy of interaction between two surfaces of material (s) immersed in water; $\Delta G_{\mathrm{SWS}}^{\mathrm{Tot}}$, total surface free energy of interaction between two surfaces of material (s) immersed in water.

\subsection{Hydrophobicity}

By calculating the surface tension of each material and of the cells, it was possible to determine the corresponding degrees of hydrophobicity (Table 4).

Unlike Ni, PMMA and SS are hydrophobic surfaces (negative values of $\Delta G_{\text {SWS }}$ ). The bacterial cells have a significant hydrophilic character.

\subsection{Effect of nickel on D. desulfuricans growth}

Fig. 2 presents the results of a representative assay where suspended SRB were cultivated with different nickel concentrations. It appears that nickel had a positive impact on bacterial growth when compared to the control, especially for nickel concentrations up to $8.52 \mu \mathrm{M}$.

Table 5 presents the values of the specific growth rates of SRB with different nickel concentrations. The values of the specific growth rates of $D$. desulfuricans suspensions were significantly higher compared to the control when nickel was added to the culture medium in the following concentrations 0.85 ,

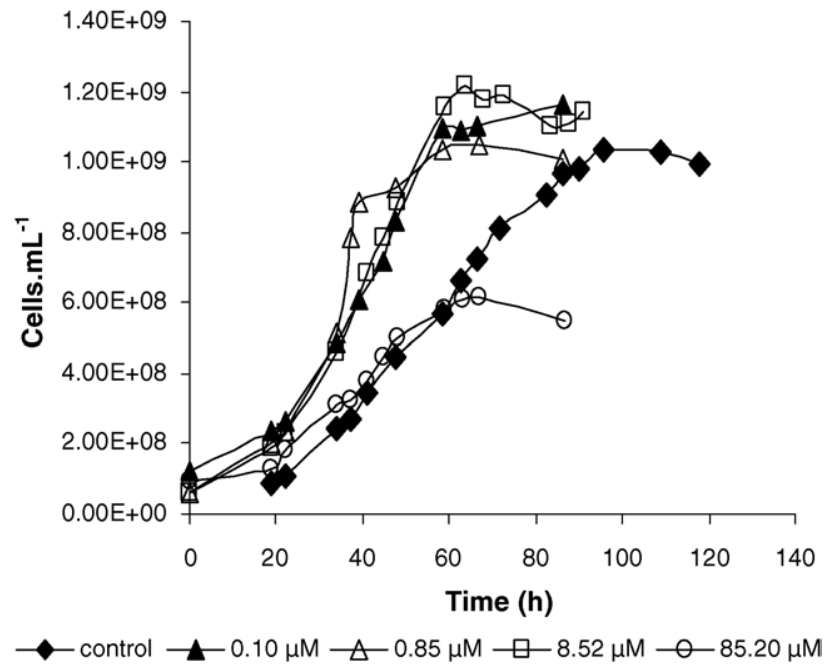

Fig. 2. Influence of nickel (Ni) concentration on suspended culture growth for a representative assay. (The absorbance values were transformed into cellular concentration using calibration curves determined for each nickel concentration and for the control medium.)
Table 5

Specific growth rates of $D$. desulfuricans with different concentrations of nickel

\begin{tabular}{ll}
\hline $\mathrm{Ni}^{2+}(\mu \mathrm{M})$ & $\mu\left(\mathrm{h}^{-1}\right)$ \\
\hline Control & $0.023 \pm 0.004$ \\
0.10 & $0.034 \pm 0.005$ \\
0.85 & $0.048 \pm 0.010$ \\
8.52 & $0.039 \pm 0.003$ \\
85.2 & $0.045 \pm 0.002$
\end{tabular}

Values are reported as average \pm standard deviation.

8.52 and $85.20 \mu \mathrm{M}$ (Anova test, $p=0<0.05$ and Bonferroni test, $p<0.05)$.

\section{Discussion}

The results of the adhesion assays (Fig. 1) show the highest bacterial density in the case of nickel followed by stainless steel and polymethylmethacrylate.

Since nickel presented the lowest hydrophobicity (Table 4) but a surface tension and roughness similar to stainless steel (Tables 2 and 3), it can be concluded that in the present case these properties are not able to differentiate the adhesion mechanism of $D$. desulfuricans to the two metallic materials. Furthermore, although Ni showed the highest electron-donor ability $\left(\gamma^{-}\right)$of the three materials (Table 3 ), which could in theory positively affect the bacterial interaction by establishing acid-base Lewis interactions with the microbial cell, $D$. desulfuricans presented no electron-acceptor ability $\left(\gamma^{+}\right)$(Table 3$)$, so no acid-base Lewis interactions could be expected to be established. This suggests that this kind of interaction might not have a particular influence on the bacterial adhesion to this surface.

Stainless steel 304 was characterised by a higher roughness than PMMA. This might also explain the higher number of adhered cells on the metallic substratum [20,21] although some other studies demonstrated no correlation between stainless steel roughness and bacterial adhesion [22]. On the other hand, its higher degree of hydrophobicity compared with the plastic material might also influence the bacterial adhesion on the metallic substratum [8]. Additionally, the surface tension values of substrata (Table 3 ) suggest that the adhesion of $D$. desulfuricans, characterised by a high electron-donor ability $\left(\gamma^{-}\right)$, may be favored to the stainless steel surface that presented a higher electron-acceptor character $\left(\gamma^{+}\right)$than PMMA.

Our results show that factors other than physical properties, such as roughness, surface tension and hydrophobicity, are clearly influencing bacterial adhesion to nickel surface.

Another hypothesis to explain our results is the effect of the surface chemical composition on bacterial adhesion. In a previous study, Feron [11] showed that the attachment of Desulfovibrio vulgaris to alloyed steels was mainly related to the steel composition and to the toxic effect of the alloying elements. George et al. [10] demonstrated that the released of iron from sensitised stainless surface may favour the attachment of Pseudomonas species to this surface. Sreekumari et al. [23] also proved that high nitrogen steels is a preferred substratum compared to stainless $304 \mathrm{~L}$ for nitrifying bacteria adhesion. 
The data obtained in the present work (Fig. 2 and Table 5) revealed that nickel positively affected the growth rate of $D$. desulfuricans. In fact, concentrations of nickel between 0.85 and $85.20 \mu \mathrm{M}$ markedly increased the specific growth rate of D. desulfuricans (Table 5). Furthermore, bacteria growing in $\mathrm{Ni}$ implemented media were consuming substrates (lactate and sulphate) and producing acetate significantly faster than in the control medium, which is in good agreement with the data of the specific growth rates. It should be pointed out that there are contrasting reports on the effects of metal ions on sulphatereducing bacteria $[11,24,25]$ but unfortunately direct comparison between studies is not possible due to the use of different growth media and experimental conditions that may change metal's bioavailability: $\mathrm{pH}$, presence or absence of reducing agents, metal chelators, presence of phosphate and carbonate buffers, organic ligands in the growth medium [26,27].

Under the conditions of this experiment (SRB were developed in a modified Postgate $\mathrm{C}$ medium containing no nickel), nickel seemed to be limiting for the growth of $D$. desulfuricans. Nickel ion has been shown to be an essential micronutrient for many micro-organisms $[28,29]$. Moreover, it has been recognised that it is incorporated into at least four microbial enzymes [30], such as the hydrogenase of sulphate-reducing bacteria. While nickel seemed to be a growth-rate limiting factor, lactate is considered a stoichiometric limiting nutrient, being the first nutrient to become exhausted during the $D$. desulfuricans growth. It should be emphasized that kinetic limiting factor limits the growth rate but not necessarily the extent of the reaction [31]. In fact, SRB started to grow with the same lactate concentration and reached the same residual concentration of this organic compound at the stationary phase of growth, leading to a similar cellular concentration, except for the highest tested nickel concentration $(85.20 \mu \mathrm{M})$, suggesting that this concentration is slightly inhibitory for the stoichiometry of the microbial reactions (data not shown).

According to our results on the effect of nickel on SRB growth and the referred literature, the possible release of small amounts of nickel from the metallic surface [14,32] could explain the higher number of adhered cells to this surface.

The absence of nickel and a lower roughness could explain the lower attachment to PMMA as compared to the two metallic materials, but do not explain the differences observed between the two metals ( $\mathrm{SS}$ and Ni) because both contain nickel, although with different mass percentages, and display similar roughness. On the other hand, the values of hydrophobicity and the electronacceptor parameter of the surface tension $\left(\gamma^{+}\right)$can be used to compare the behaviour of SS and PMMA, but do not justify the extent of adhesion to nickel.

The difference of SRB adhesion on stainless steel and nickel surfaces may be explained by the following: stainless steel passivity in an aqueous environment is due to an intact and tenacious chromium oxide layer. In the present conditions, this film provides a protective coating over the surface, that prevents the dissolution of metal species and, therefore, reduced nickel concentration is expected at the solid/liquid interface. In the case of nickel, there is a film of hydroxide with a not negligible solubility in the present conditions [33]. The concentration of nickel should therefore be greater at the nickel surface compared to the stainless steel substratum. The availability of nickel ions at the surface may be an important factor influencing the initial attachment of SRB cells [34].

Although no proven explanation for the mechanism of adhesion of $D$. desulfuricans to nickel substratum can be given at the moment, it may be speculated that cellular structures on SRB surface or chemotaxis towards a nickel releasing surface may play a role in the observed phenomena. In fact, bacterial chemotaxis towards metallic surfaces was previously demonstrated [35]. Furthermore, the adhesion of the sulphate-reducer to nickel may be associated to cellular structures, such as adhesins, that establish specific interactions with nickel, as it has been recognised for the interaction LPS/Fe [36]. It could be speculated that this specific structure of bacterial surface, besides mediating the microbial adhesion to the metallic substratum, may also be part of a metal-uptake system. Several studies previously emphasized the relevance of highly specific interactions between metallic substrata and structures of the outermost surface of sulphatereducing bacteria. López-Jiménez et al. [37] demonstrated that SRB strains isolated from a biofouling gas pipeline were able to produce adhesion proteins (adhesins) when put in contact with carbon steel. Beech and Gaylard [38] have shown that a specific surface macromolecule, a lipopolysaccharide (LPS), was involved in the adhesion of $D$. desulfuricans to mild steel surfaces. It was also suggested that extracellular sulphur-containing proteins and amino functional groups may contribute to the attachment of micro-organisms to metal substrata [39].

The authors suggest that these mechanisms should be examined in detail in the follow up of the present work.

\section{Conclusion}

Adhesion of $D$. desulfuricans was shown to be more significant on Ni surfaces than on SS or PMMA surfaces. Despite its high hydrophobicity, PMMA supported less bacteria as compared to the metallic surfaces due to a smaller value of roughness and to the absence of nickel. Concerning the metallic surfaces, differences in hydrophobicity and in surface tension $\left(\gamma^{+}\right)$did not justify the higher adhesion to nickel as compared to stainless steel. A difference in nickel availability at the metallic surfaces may be an important factor influencing the initial attachment of SRB cells to SS and nickel. It could be that the adhesion of $D$. desulfuricans to these surfaces is not mediated by usual physico-chemical interactions but rather by specific interactions involving cellular structures on the SRB surface or by a chemotaxis mechanism towards a nickel releasing surface.

A future step will be to check the existence of a structure of SRB surface engaged in adhesion and its specific interaction with nickel or the chemotaxis phenomena in order to a better understanding of the mechanism of adhesion of $D$. desulfuricans to nickel substratum.

\section{Acknowledgement}

The authors acknowledge the financial support of Programme Praxis XXI (Grant Praxis XXI/BD/13462/97). 


\section{References}

[1] B. Little, P. Wagner, F. Mansfeld, Electrochim. Acta 37 (12) (1992) 2185.

[2] G. Geesey, I. Beech, P. Bremer, B.J. Webster, D.B. Wells, in: J. Bryers, (Eds.), Biofilms II Process Analysis and Applications, New York, 2000, pp. 281-325.

[3] W.A. Hamilton, Microbially influenced corrosion in the context of metal microbe interactions, in: C.A.C. Sequeira (Ed.), Proceedings of the 4th International EFC Workshop, Lisboa, Portugal, 1999, p. 1.

[4] W.A. Hamilton, Biofouling, 19 (1) (2003) 65

[5] R. Javaherdashti, Anti-corrosion Methods Mater. 46 (3) (1999) 173.

[6] G.R. Gibson, Appl. Bacteriol. 69 (1990) 769.

[7] J.M. Odom, ASM News 56 (9) (1990) 473.

[8] R. Oliveira, J. Azeredo, P. Teixeira, in: S. Wuertz, P.L. Bishop, P.A. Wilderer (Eds.), Biofilms in Wastewater Treatment, 2003, pp. 211-231.

[9] M.B. Valcarce, J.P. Busalmen, S.R. Sánchez, Int. Biodeterior. Biodegrad. 50 (1) (2002) 61.

[10] R.P. George, P. Muraleedharan, K.R. Sreekumari, H.S. Khatak, Biofouling 19 (1) (2003) 1

[11] D. Feron, Attachment of Desulfovibrio vulgaris to steels: influence of alloying elements, in: A.K. Tiller, C.A.C. Sequeira (Eds.), Proceedings of the 3rd International EFC Workshop, Estoril, Portugal, 1994, p. 119.

[12] P.A. Schweitzer, in: P.A. Schweitzer (Ed.), Corrosion Engineering Handbook, Marcel Dekker Inc., New York, 1996, p. 76.

[13] H.H. Uhlig, in: Urmo, S.A. de Ediciones (Ed.), Corrosion Y Control de Corrosion, Urmo, S.A. de Ediciones, Bilbao, 1975 (Chapter 5).

[14] B. Beverskog, I. Puigdomenech, Corros. Sci. 39 (5) (1997) 969.

[15] W.Z. Friend, in: W.Z. Friend (Ed.), Corrosion of Nickel and Nickel-base Alloys, John Wiley and Sons, New York, 1980.

[16] H.J. Busscher, A.H. Weerkamp, H.C. van der Mei, A.W. van Pelt, H.P. Jong, J. Arends, Appl. Environ. Microbiol. 48 (5) (1984) 980.

[17] C.J. Van Oss, M.K. Chaudhury, R.J. Good, Adv. Colloid Interface Sci. 28 (1987) 35

[18] C.J. Van Oss, R.F. Giese, Clay Minerals 43 (1995) 474.

[19] C.J. Van Oss, R.J. Good, M.K. Chaudhury, Langmuir 4 (1988) 884.

[20] L. Coquet, P. Cosette, G.A. Junter, E. Beucher, J.M. Saiter, T. Jouenne, Colloid Surf. B: Bioint. 26 (4) (2002) 373.
[21] R.F. Mueller, W.G. Characklis, W.L. Jones, T. Sears, Biotechnol. Bioeng. 39 (1992) 1161

[22] L. Boulangé-Petermann, J. Rault, M. Bellon-Fontaine, Biofouling 11 (3) (1997) 201

[23] K.R. Sreekumari, K. Takao, T. Ujiro, Y. Kikuchi, ISIJ Int. 44 (5) (2004) 858.

[24] M.S. Ram, L. Singh, M.V.S. Suryanarayana, S.I. Alam, Water Air Soil Pollut. 117 (2000) 305.

[25] C.W.S. Cheung, I.B. Beech, The influence of metal ions on the activity of hydrogenase in sulphate reducing bacteria, in: A.K. Tiller, C.A.C. Sequeira (Eds.), Proceedings of the 3rd International EFC Workshop, Estoril, Portugal, 1994, p. 169

[26] S.R. Poulson, Geomicrobiol. J. 14 (1997) 41

[27] R.K. Sani, G. Geesey, B.M. Peyton, Adv. Environ. Res. 5 (2001) 269

[28] R.E. Speece, in: Anaerobic Biotechnology for Industrial Wastewaters, Archae Press, Nashville, 1996, pp. 221-244.

[29] H. Mann, in: J. Wase, C. Forster (Eds.), Biosorbents for Metal Ions, Taylor and Francis Ltd., UK, 1997, pp. 105-106.

[30] R.K. Thauer, TIBS November (1980) 304.

[31] W.G. Characklis, in: W.G. Characklis, K.C. Marshall, (Eds.), Biofilms, New York, 1990, pp. 161-163.

[32] M. Pourbaix, in: Atlas d'Equilibres Electrochimiques à $25^{\circ} \mathrm{C}$, Gauthier Villars \& Cte, Paris, 1963 (section 12.3).

[33] J. Chivot, in: C.E.A. Andra, (Ed.), Thermodynamique Des Produits De Corrosion, Paris, 2004 (Chapter 7).

[34] I.B. Beech, C.C. Gaylard, in: Proceedings of the 2nd EFC Workshop on Microbial Corrosion, European Federation of Corrosion, Portugal, 1991. p. 61.

[35] S.R. Sanchez, D.J. Schiffrin, J. Electroanal. Chem. 403 (1996) 39

[36] G. Bradley, C.C. Gaylarde, J.M. Johnston, J. Gen. Microbiol. 130 (1984) 441.

[37] G. López-Jiménez, S. Leborgne, O. Loera, F. Ramirez, O. Monroy, L.L. Fernández, in: Biofilms and Adhesion Protein in Anaerobe Bacteria Isolated from Mexican Gas Pipelines, Proceedings of the 8th International Petroleum Environmental Conference, Houston, Texas, 2001.

[38] I.B. Beech, C. Gaylarde, J. Appl. Bacteriol. 67 (1989) 201.

[39] G. Chen, S.V. Kagwade, G.E. French, T.E. Ford, R. Mitchell, Corrosion 52 (12) (1996) 891 